\title{
Riboflavin 5'-Phosphate Sodium
}

National Cancer Institute

\section{Source}

National Cancer Institute. Riboflavin 5'-Phosphate Sodium. NCI Thesaurus. Code C48016.

The phosphate sodium salt form of riboflavin, a water-soluble and essential

micronutrient that is the principal growth-promoting factor in naturally occurring vitamin

B complexes. Riboflavin phosphate sodium is converted to 2 coenzymes, flavin mononucleotide (FMN) and flavin adenine dinucleotide (FAD), which are necessary for energy production by aiding in the metabolism of fats, carbohydrates and proteins and are required for red blood cell formation and respiration, antibody production and for regulating human growth and reproduction. Riboflavin phosphate sodium is essential for healthy skin, nails and hair growth. 